\title{
The Thoreauvian Pilgrimage: The Structure of an American Cult
}

\section{Citation}

Buell, Lawrence. 1989. The Thoreauvian Pilgrimage: The structure of an American cult.

American Literature 61(2): 175-199.

\section{Published Version}

http://dx.doi.org/10.2307/2926692

\section{Permanent link}

http://nrs.harvard.edu/urn-3:HUL.InstRepos:2635305

\section{Terms of Use}

This article was downloaded from Harvard University's DASH repository, and is made available under the terms and conditions applicable to Other Posted Material, as set forth at http:// nrs.harvard.edu/urn-3:HUL.InstRepos:dash.current.terms-of-use\#LAA

\section{Share Your Story}

The Harvard community has made this article openly available.

Please share how this access benefits you. Submit a story.

\section{Accessibility}




\section{The Thoreauvian Pilgrimage: The Structure of an American Cult}

LAWRENCE BUELL

Oberlin College

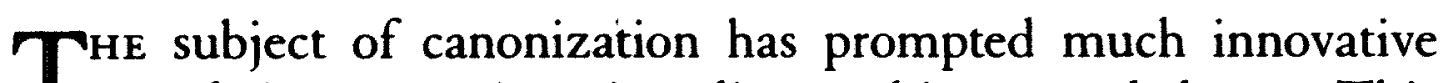
1 work in recent American literary history and theory. This scholarship has established that canons are culture-specific instruments of promotion and exclusion, and it has begun to explain canonical formation and change in terms of models of cultural hegemony more complex and hard-headed than traditional historicists and New Critics employed: models that take into account not just aesthetic fashion and the philosophical temper of the age but also the more tangible power conferred by race, gender, and class. Since it began as a challenge to the received conception of who are the major authors deserving close study, the newer scholarship has understandably concentrated on the claims of figures marginalized by the received canon and on questioning the unexamined assumptions behind such exclusions. Little has been written about the phenomenon of canonical investment itself: that is, the rituals of remembrance through which those regarded for whatever reason as literary heroes become enshrined. Hence the present article, which examines the major forms of public reverence for Thoreau in particular and Transcendental Concord in general. Since Thoreau has become the closest approximation to a folk hero that American literary history has ever seen, and since Concord is still America's most sacred literary spot, this will be a case study representative in the Emersonian rather than in the statistical sense. But by the same token it should help to show that the sacral vocabulary drawn from biblical studies and hagiography by critical discussions of literary canonization points to patterns of behavior and experience that run deeper than such analogizing generally claims, patterns that substantiate the present climate of skepticism toward

American Literature, Volume 6r, Number 2, May 1989. Copyright (C) 1989 by the Duke University Press. CCC $0002-9831 / 89 / \$ 1.50$. 
canonization as interest-group politics yet also suggest there is more to literary cultism than just that.

My essay concentrates specifically on Thoreau's Walden as a site of pilgrimage and as a prototype for imitation. To sharpen the focus of discussion, I recur at intervals throughout the essay to a particular devotee, John Muir, who for several reasons is especially useful for present purposes. His testimony is extensive; it illustrates Thoreauvian iconography in the process of formation; it illustrates the ideological ambiguities and complexities to which I have alluded; it is in many ways typical as well as unique; and it has a special historical importance in view of Muir's achievements in his own right and the role of those achievements as well as Muir's direct promotional efforts in perpetuating Thoreau's memory.

On Thursday 7 June I 893 John Muir visited Concord, during his first trip east after achieving fame as writer, conservationist, naturalist, and pastoral solitaire of Yosemite Valley. This was part of a strenuous round of introductions and visitations orchestrated by Muir's editor, Robert Underwood Johnson. "Mr. Johnson is making me go to all the pretty \& famous places \& people whether I will or no," wailed Muir in mock-exhaustion after his return to Boston. ${ }^{1}$ But in truth Muir had enjoyed himself hugely.

The trip to Concord became one of the highlights of Muir's visit. He "wandered through the famous Emerson village"; saw the Concord Bridge of Revolutionary (and Emersonian) fame; visited the houses of Emerson, Hawthorne, and Thoreau; and laid flowers on the graves of both Thoreau and Emerson, admiring Emerson's rugged unmarked granite monument. "I did

1 To Helen Muir, 9 June 1893 ms. letter, John Muir Papers, University of the Pacific, Stockton, Cal., hereafter abbreviated JMP. This and other Muir mss. I have examined in the Chadwyck-Healey comprehensive microfilm edition of Muir's papers. For an index, see Ronald H. Limbaugh and Kirsten E. Lewis, eds., The Guide and Index to the Microform Editions of the John Muir Papers, 1858-1957 (Alexandria, Va.: ChadwyckHealey, 1986). This and other mss. quotations from JMP are quoted by permission of John Muir Papers, Holt-Atherton Pacific Center for Western Studies, University of the Pacific, Copyright $198_{4}$ Muir-Hanna Trust. Generous support from the Guggenheim Foundation and Oberlin College assisted the completion of this article, as did the advice of Grover Zinn and Thomas Blanding. 
not imagine I would be so moved at the sight of resting-places of these grand men," he confessed in a long letter to his wife that records the Concord visit in great detail, even by Muir's voluble standard as a producer of chatty letters home during his many long excursions. "I could not help thinking how glad I would be to feel sure that I would also rest here." From there Muir and Johnson walked to Walden Pond, "a beautiful lake about half a mile long, fairly embosomed like a bright dark eye in wooded hills of smooth moraine gravel and sand, and with a rich leafy undergrowth of huckleberry, willow, and young oak bushes, etc., and grass and flowers in rich variety." Struck by its peaceful beauty, Muir thought it "no wonder Thoreau lived here two years. I could have enjoyed living here two hundred years or two thousand." ${ }^{2}$ Before leaving, Muir picked a bouquet of flowers and sent them to his daughter Helen, later to be followed by pictures of Emerson and Thoreau, and of Walden Pond. "Some day," he wrote his other daughter Wanda, "you \& Mama \& Helen will go there \& see where Thoreau lived \& Emerson so much greener \& fresher \& calmer than Martinez is, \& so many good \& great people lived there." ${ }^{3}$

The visit to Concord concluded with dinner at the home of Edward Emerson, who seemed to Muir to look just like his father, whom Muir had met during a memorable encounter in Yosemite Valley a dozen years before. Muir was especially delighted when the younger Emerson's father-in-law, "a college mate of Thoreau who knew Thoreau all his life," greeted him, when they were introduced, "as if I were a long lost son. He declared he had known me always, and that my name was a household word." 4

Although the Concord visit started as a forced excursion, it clearly became a pilgrimage in a deeply meaningful sense, as well as part of a larger ritual of induction into Brahmin culture, leading during the next few years to a close friendship with Muir's Boston host and fellow botanist Charles Sprague Sargent, an honorary degree from Harvard, and, ironically for

2 To Louie Strenzel Muir, 12-13 June 1893 , in William Frederic Bade, The Life and Letters of John Muir (Boston: Houghton Mifflin, 1924), II, 266-68.

3 To Wanda Muir, 14 June 1893 and 20 June 1893 ms. letters, JMP; quotation from the latter.

${ }^{4}$ Bade, II, 269. 
R. U. Johnson of New York's Century Publishing Company, the capture of Muir's literary talents for the Atlantic and Houghton Mifflin.

Muir's visit to the Northeast completed a process begun many years before during his memorable encounter with Emerson in 1871. Characteristically overcoming his country-boy bashfulness with an excess of bravado, Muir invited the old man for a twoweek camp-out with himself as guide. Emerson's eastern escort headed Muir off, but not before he had charmed the sage into an initial acceptance and a permanent enthusiasm for Muir. Back home, Emerson inconsistently but typically issued a ringing invitation to Muir to leave his hermitage, come east, and stay with him, insisting that Muir would find this cosmopolitan environment more invigorating than his own. Muir responded in the Thoreauvian vein, urging that Emerson revisit the Sierras, professing not to "understand the laws that control you to Concord," reassuring the sage in psalmic tones that "I know smooth places on the mountains \& you will never be wearied." ${ }^{5}$ But finally it was Muir who accepted Concord's terms. Three years after his eastern visit, when he was offered the Harvard degree, Muir's first thought was again to resist by parading the persona of the California rustic, but on second thought to accept because "From the very beginning of my studies it was Harvard men," starting with Emerson, "who first hailed \& cheered me." 6

Muir was thus no ordinary Concord pilgrim. He was returning, as it were, Emerson's previous invitation, and as a dignitary in his own right on whom the master had conferred a symbolic sonship that was fortuitously confirmed by the actual son's own father-in-law. In other fundamental ways, however, his experience was representative of the hundreds of records left by the millions of pilgrims that came to Concord from the midnineteenth century to the present.

The most fundamental common thread was the theme of pilgrimage itself. Among all American places made famous by

5 Bade I, 259-6o (for Emerson's 5 February 1872 letter to Muir); The Letters of Ralph Waldo Emerson, ed. Ralph Leslie Rusk (New York: Columbia Univ. Press, 1939), VI, 202 (for Muir's 18 March 1872 letter to Emerson).

6 Muir to Robert U. Johnson, 3 June 1896 ms. letter, Robert Underwood Johnson papers, University of California, Berkeley, quoted by permission of Bancroft Library. 
literary associations, Concord had already long been and still remains today the most visited and the most luminous with the sense of the sacred. I use this last term with entire seriousness. Customary though it has become to speak of the American literary "canon" and the process of "canonization" by which writers become recognized as major, the full extent to which the patterns of hagiography have come to invest some of these figures has not been recognized. One begins to appreciate this when one takes note of the similarities between the pilgrimage to Concord and the findings of historical and anthropological students of religious pilgrimage as ritual process.

In particular, I follow Victor and Edith Turner's analysis of Christian pilgrimage, both ancient and modern. Pilgrimage for the Turners is a "liminoid" experience offering a temporary "liberation from profane social structures" and spiritual renewal at the journey's end through the exchange of these structures for a sacred realm of significant symbols (in the form of shrines, icons, and the like) that usher the pilgrim imaginatively "into the culturally defined experiences of the founder." Within the Christian tradition, the example par excellence is the via crucis, the reenactment by the pilgrim of Jesus' procession to the cross. Such symbolic actions express what the Turners call "root paradigms," that is, "cultural models for behavior" that express "fundamental assumptions underlying the human societal bond."

When Muir's account is compared with that of other Concord travelers and with the model I have begun to unfold, it is clear that his visit was at least a borderline example of pilgrimage in the literal sense. Some telltale signs are Muir's investment of Concord and environs in an atmosphere of holy calm-his sense of Sleepy Hollow and Walden Pond as attractive final resting places for himself; his sense of treading in the footsteps of the "great men" (he vicariously self-inters beside the Transcendentalists, he vicariously enacts a grander version of Thoreau's sojourn); the concentration of his attention and reverence on the famous shrines (including even the younger Emerson's home, a mandatory stop for the well-connected); and his acquisition of iconic mementoes, the flora and the photographs.

The selectivity of Muir's account in the interest of sacraliza-

7 Image and Pilgrimage in Christian Culture (New York: Columbia Univ. Press, 1978), pp. 9, I1, 249, 10, 248. The title belies the fact that the Turners frequently discuss Christian pilgrimage with reference to diverse other regional and world religions. 
tion is especially apparent in his celebration of Walden Pond itself. No mention is made of the busy railroad at the west end. No mention is made of the commercialization of the adjacent pond area, which was in some ways more meretricious in the I 890 os than it is today. "You cannot get away from the Walden Fourth-of-July Picnic feeling," wrote a visitor just two years after Muir, "not even in Thoreau's own cove," where "great beams" projected out into the water where once a bath-house stood. Two years later, another pilgrim was disconcerted to see a "gaily draped pleasure-craft filled with . . . picnickers" floating on the lake and "gaudy signs inscribed 'Walden Lake Picnic Grounds." " Muir apparently saw Walden later in the afternoon, when the activity might have subsided; still, there must have been a number of blemishes, compromising to his vision, that he chose not to see or at least to record. It is notable that Muir, unlike some more citified visitors of the day for whom Walden seems really to have looked primitive, was under no illusions that this was wilderness. "It is only about one and a half or two miles from Concord, a mere saunter, and how people should regard Thoreau as a hermit on account of his little delightful stay here I cannot guess," writes the ex-hermit of Yosemite. Yet even here the point Muir makes is that Walden is near civilization, not that it bears the marks of civilization.'

This tendency to over-pastoralize Walden has persisted in the face of staggering visitation statistics (thirty thousand Concord pilgrims annually on the eve of World War I, a half million to the pond alone in the late 1970 ) ${ }^{10}$ and protest, starting at least as early as the $1890 \mathrm{~s}$, against the exploitation of the pond area. Upon the centenary of Thoreau's experiment, naturalist Edwin Way Teale found Walden "wilder in 1945 than it was ... in I 845," despite the incursion of as many as 10,000 picnickers and bathers a day. In 1969, a writer for American Forests found Walden "as beautiful, wood-fringed, and satisfying to escapees from today's urbanization as Henry David Thoreau described

${ }^{8}$ Kate Tryon, “A Day Afield," rpt. Kenneth W. Cameron, ed., New England Writers and the Press (Hartford, Conn.: Transcendental Books, 1980), pp. 255-56; Philip G. Hubert, Jr., "At Thoreau's Pond," Book Buyer, 14 (1897), 550.

9 To Louie Strenzel Muir, 12-13 June 1893, in Bade, II, 268.

10 Henry Beers, "A Pilgrim in Concord," Four Americans (New Haven: Yale Univ. Press, 1920), p. 77; Lee Barber, "Walden-They Come in All Seasons, For All Reasons," Concord Journal, i Dec. 1977, Suppl., pp. I, 5 (statistics for 1976 and 1977). 
its environs nearly 1 25 years ago." Even in 1979, another visitor supposed that "the place seems pretty much as it must have been when Thoreau quit the cabin and went back to Concord." "1 These reactions, like Muir's, attest more to the perceiver's power to see the landscape through Thoreauvian eyes than to the actual state of Walden at the time of viewing. As to the latter, the most one can say is that incursions on the pond have been controlled to the extent that it is still possible for observers to see the environment as in a more natural state than might have been expected: the contrary evidence isn't (yet) so overwhelming as to prevent the resolute from making the transition to the liminoid, sacralized vision.

The three just-cited visitors' accounts of the past half-century differ from Muir's in being preoccupied solely with Walden Pond. They delete the rest of the town of Concord, whereas for Muir the visit to Walden was only one of several high points. Muir, however, exemplifies the shift in the central focus of the Concord pilgrimage that was then in process. During Thoreau's lifetime and for some time thereafter, Emerson and Hawthorne were the great literary figures one came to see or track; they and the allure of Concord's Revolutionary fame kept the tourist/ pilgrim's interests focused more on the town proper than on the woods. Even as late as the turn of the century, some tourist guides made no mention of Walden Pond ("too far from the center of town for the average tourist to visit," judged one in I895), though they inevitably made some reference to Thoreau as an author. A typical promotion piece, issued on the occasion of the Emerson Centenary (1903), placed Emerson first (as probably "the best known of anyone who has ever lived here"), followed by Hawthorne. In 1904, the decade's most famous literary pilgrim, Henry James, got as far out of the town center as the Concord River but, while paying Thoreau tribute in a hasty parenthetical phrase, insisted on associating even the sylvan places of Concord with Emerson's genius: "not a russet leaf fell for me, while I was there, but fell with an Emersonian drop." 12

11 Teale, "Wildlife at Walden," The Lost Woods (New York: Dodd, Mead, 1946), p. 273; H. D. Crawford, "Thoreau Country," American Forests, 75 (Nov. 1969), 21; Caskie Stinnett, "It Wasn't as Easy as It Seemed," Atlantic, 243 (1979), 30.

12 For the record of a comparatively early pilgrimage (1860), see William Dean 
But this was the wave of the past. Thoreau's handful of devoted disciples had already begun to predict in the 1890 os that "Thoreau will continue to grow, while Emerson will become more and more of a back number." In 1897, a townswoman in the literary souvenir business told a visitor that Thoreau items sold better than Emerson and Hawthorne memorabilia. In 1898 , Thomas Wentworth Higginson noted that Thoreau's manuscript letters were fetching the same as Hawthorne's ( $\left.\$ 17.5^{\circ}\right)$, four times Longfellow's. In 1904, an enterprising Concordian advertised in a Boston paper that he owned some of the remaining timbers of Thoreau's cabin, presumably displayable at a price. In 1906 Good Housekeeping noted that Thoreau hatpins, made from the nuts of a tree he supposedly sowed in the Sudbury River, were being sold in Concord. More importantly, the same year, Thoreau became the first American man-of-letters, including Emerson, to have his private journal published in full. Reappraising Concord culture in 1919, forty years after having been a student in the Concord School of Philosophy, Henry Beers of Yale University confessed that Thoreau was interesting him more and more, Emerson less, and registered little surprise at Franklin Benjamin Sanborn's recently quoted statement that Thoreau was the Concordian most likely to endure. ${ }^{13}$

With the rise in Thoreau's prestige came an increasing tendency to envisage Concord as an oasis of pastoral felicity and Walden as its spiritual center. This tendency, of course, had prior roots in the Concord Transcendentalists' highly self-conscious

Howells, "My First Visit to New England," Harper's Monthly, 89 (1894), 441-51. Quotations from Souvenir of Concord, Mass. (Concord: Henry J. Walcott, Jr., 1895); Concord in History and in Literature: A Tourist's Guide (Concord: Albert Lane, [1903?]), pp. 40-45; James, The American Scene, ed. Leon Edel (1907; Bloomington: Indiana Univ. Press, 1968), pp. 264-65. Note, however, that the most popular late nineteenth-century Concord guidebook, George B. Bartlett's The Concord Guide Book (Boston: D. Lothrop, I88o), which went through at least eleven editions by 1885 , put in a very strong plug for Walden Pond, which was described under the heading of "Thoreau's Home" (p. 63).

${ }^{13} \mathrm{~S}$. A. Jones to A. W. Hosmer, 18 December 1896 , in Fritz Oehlschlaeger and George Hendrick, eds., Toward the Making of Thoreau's Modern Reputation (Urbana: Univ. of Illinois Press, 1979), p. 270; Higginson, "Henry David Thoreau," American Prose, ed. George Rice Carpenter (New York: Macmillan, 1898), p. 340. For the tidbits on the timber and hatpins, see rpts. in Thoreau Society Bulletin, 152 (Summer 1980), 7 ; 22 (January 1948), 4. For Beers's retrospect, see his "Pilgrim in Concord," p. 78. For important studies of Thoreau's changing reputation during the period of its rise to the point of canonization, see especially the Introduction to Oehlschlaeger and Hendrick and the review of other pertinent scholarship in Walter Harding and Michael Meyer, The New Thoreau Handbook (New York: New York Univ. Press, 1980), pp. 202-24. 
rusticity as they defined themselves over and against BostonCambridge culture, a legacy reinforced by Concord's ability to maintain the appearance of a small village in the face of nearby urban buildup. Both earlier and later bucolic imagings were in good part self-mystifying illusions: far from being simple rustics, the Concord group were cultured intellectuals of cosmopolitan taste, and Concord itself was networked into the greater Boston area by the railroad and other economic institutions. ${ }^{14}$ But that is a side-issue. The emotional fact of the matter, if not the literal truth, was that Concord was from the very start of the Transcendentalist movement poised to become a spot to which literary pilgrims might repair in the sense of having left the profane metropolis to find solace in the sacred grove; and that the growth of Thoreau's haunts as a magnet for pilgrims was an intensification of a liminoid structure extant from the time Margaret Fuller started visiting the Emersons in the 1830 , long before Thoreau became famous. This was the deepest sense in which Thoreau can be said to have realized the Emersonian vision and gone beyond it.

Once Concord actually became noted as the resort of bucolic philosopher-literati, its pastoral mystique was redoubled. The first canonical work outside the Transcendentalist fold itself in which we can see this process at work is the title essay of Hawthorne's Mosses from an Old Manse (1845), a cozily ruminative essay that renders in a droller and more self-conscious way the epistolary lyricism expressed, especially by Sophia Hawthorne, during the Hawthornes' honeymoon period in the house where Emerson composed Nature. In "Mosses," too, we also see the beginning of the tradition of urbanite self-consciousness about entering this liminal world and falling under its spell; Hawthorne achieves a certain distance from it by poking fun at the mystics' expense and at the idiosyncrasy of his own noncosmopolitanism during this interval of lotus-eating. In time, the Hawthornian formula of mythic pastoralism made more earthy and/or plausible through a certain comic detachment became

14 With regard to nineteenth-century Concord's cosmopolitanization and its ambivalent relation with greater Boston, see especially Robert A. Gross, "Concord, Boston and the Wider World: Transcendentalism and Urbanism," New Perspectives on Concord's History, ed. William M. Bailey et al. (Concord: Foundation for Humanities and Public Policy, 1983), pp. 95-1 18. 
the well-worn formula of popular journalism. Though it is impossible to set an exact dateline here, the advent of the post-Civil War era seems to have been a point of transition. "A more peaceful village you can find nowhere," writes one tourist of the late I86os. "You may walk a mile on the main road without meeting a single human being." Concord "is a very quiet place," another agrees, revealingly adding: "a place, above all others, whefe one would think poets, dreamers, and philosophers would live." "A little rural world curtained off for slumber and drowsy dreams," writes another, in $1870 .{ }^{15}$ These travelers came expecting to find elysium, which made elysium all the easier to find.

Hence, in descriptions of Walden Pond from the same period, we find illogically but understandably two opposite messages. First, that Walden, owing to the fame of Thoreau's book as well as the convenience of the Boston and Fitchburg Railroad, had become "a pleasure resort," "a famous place for pic-nics." One reporter, interviewing latter-day hermit Edmond Hotham, ingenuously quoted him as complaining about the number of visitors who interrupted his solitude. Clearly Walden was already no longer a good place to set up a hermitage. But second, reporters insisted just as strongly as Thoreau had on Walden's unspoiled character - that it was no mundane spot but fully as special and magical as Thoreau himself had averred: "a beautiful lakelet," "a picture of delight," a body of water exceptionally "Mediterranean in its kaleidoscopic tints," etc. ${ }^{16}$ In short, Walden was being transformed from Thoreau's sacred place into the reading community's sacred place: "Tourists who know the dreamer of Walden Pond look upon it as a shrine." By the early 1870 , even an anti-Transcendentalist nature writer could affirm that "every student of nature or admirer of poetry as exemplified in life and

15 Thomas Kean, "About a Visit to Boston and Concord," Buffalo Courier, 1869, in A. Bronson Alcott, "Autobiographical Collections," 1868-71, p. 105 (Houghton Library, Harvard); "An Hour with a Philosopher," anon. I 868 newsp. clipping, ibid., p. 47; "A Visit to Old Concord," 1870 unidentified newsp. article, rpt. Kenneth W. Cameron, ed., Transcendental Log (Hartford, Conn.: Transcendental Books, 1973), p. 232.

16 Kean, op. cit.; Thomas Lang, "Walden Pond," 1870 unidentified newsp. report, rpt. Cameron, Transcendental Log, p. 187; Edward King, "Rambles in Concord-I," 1869 Springfield Republican clipping, Alcott "Autobiographical Collections," 1868-71, p. 97 (Houghton); "A Visit to Old Concord," Transcendental Log, p. 235; "Thoreau's Hermitage," 16 Jan. 1877 clipping from New York Evening Post, rpt. ibid., p. 296. 
action, who should make a visit to Walden Pond, would seek the spot which was made sacred by the two years' solitary residence of Henry D. Thoreau." ${ }^{17}$

\section{III}

A book in itself could be written about the history of the rituals that began at this point to build up around the pond site, ${ }^{18}$ simple and informal though they were compared to the great pilgrimages studied by the Turners. (Remember that we are dealing with a borderline case here.) The devotee has always been expected to stroll a bit in the woods, to look at the pondscape as if through the eyes of Thoreau himself, and to let his or her imagination saunter. Muir did all this. Beginning in 1872 , devotees have brought stones to a cairn near the cabin site. This Muir apparently did not do, possibly because he visited at a time when the area was so denuded of rocks that another visitor complained about the amount of foraging required to find a suitable offering. ${ }^{19}$ Since 1945 , when the exact cabin site was discovered, thoughtful inspection of it is also de rigueur; and so, of late, is a look at the cabin replica that sits in the parking lot across State Route 126 to the east of the lake. Conversely, some marks of homage have fallen out of favor. "He who would know Thoreau's Walden will do well to bathe in it," recommends one I9I I pilgrim, and he proceeds to depict the experiences of both spiritual and bodily refreshment in detail. ${ }^{20}$ Today the serious Thoreauvian considers swimming in Walden a form of pollution rather than a way of exorcising it.

More important, however, than any of these specific motifs, more important even than undertaking a literal visit to Walden itself is the inward experience of enacting in whatever place or mode an imitation of Thoreau's own withdrawal from organized society. Like Muir, the devotee may feel energized by

17 Wilson Flagg, The Woods and By-Ways of New England (Boston: Osgood, 1872), p. 392.

18 See for example Jeanne M. Zimmer, "A History of Thoreau's Hut and Hut Site," $E S Q, 18$ (1972), 134-40.

19 Hubert, "At Thoreau's Pond," p. 556.

20 Winthrop Packard, Literary Pilgrimages of a Naturalist (Boston: Small, Maynard, I9I I), pp. 6I-64. 
having visited the spot of Thoreau's experiment and imagined him or herself in Thoreau's place but, perhaps partly because of Thoreau's own aggressive lococentrism and warnings against literal imitation of his example, the serious pilgrim is bound to take a more "protestant" approach to pilgrimage than the one we are considering, that is, to see any act of virtue accomplished by the literal pilgrimage as trivial compared with whatever s/he can achieve in her own life by way of parallel.

Hence we find a proliferation of homesteading experiments during the past century that claim Thoreau as inspiration, directly or obliquely. These begin about a generation after Thoreau's death, not right away. I have already alluded to what might seem to be the first of these: a shanty-dwelling project at Walden Pond itself in 1869 , by Edmond Hotham, who built his hut very close to Thoreau's site. Hotham, however, does not seem to have claimed Thoreauvian influence, despite the fact that he too sought Emerson's patronage. Nor do comparable experiments from the same period. ${ }^{21}$ But as Thoreau's fame grew it became increasingly common to see each new experiment in pristine solitary living in terms of Walden as prototype. In the r88os, British utopian socialists like Edward Carpenter and Henry Salt begin to take Thoreau's gospel of simplification seriously and act it out in modified form. In I 889 appears the first elaborate literary account of a retreat to rusticity that deliberately claims Thoreau as model: a Long Island venture undertaken by journalist Philip G. Hubert, Jr., who follows his detailed, systematic autobiographical record with a passionate defense of the feasibility of Thoreau's experiment. By I9o , Paul Elmer More cannot resist seeing his brief outing in the Maine Woods as a Thoreauvian experience, even though (as More soon realized) he and Thoreau were not really temperamentally compatible. Meanwhile, in Holland, Frederik van Eeden had started a Christian Socialist commune named after Walden, and at the antipodes Australian writer Edmund James Banfield was about to embark on a twenty-five-year Walden experiment of his own

${ }^{21}$ Kenneth W. Cameron, "Thoreau's Disciple at Walden," Emerson Society Quarterly, 26 (1962), 34-44. See also Prentice Mulford, The Swamp Angel (Boston: Needham, I888), which records a very similar near-contemporary experiment in hut-building in the New Jersey Pine Barrens, in apparent innocence of Thoreau as a precedent. 
on a Pacific island. ${ }^{22}$ A generation later, it seemed self-evident that American hermitage-retreat literature like Henry Beston's The Outermost House (1928: about a winter spent in a shack on a Cape Cod beach) and Aldo Leopold's Sand County Almanac (1948: centered at the author's camp in Wisconsin) should be seen as Thoreauvian documents, even though they make little direct reference to Thoreau. ${ }^{23}$

The greatest spate of biographical and autobiographical narratives of people who have lived their lives avowedly according to Thoreau's example has come since World War II, since the centennial of the Walden experiment itself. A few of these are of conspicuous literary merit, like Annie Dillard's Pilgrim at Tinker Creek (1974). Most are ephemeral, like Charles Seib's The Woods: One Man's Escape to Nature (I97I, rural North Carolina); Gilbert Byron's Cove Dweller (1983, Maryland's eastern shore); George Sibley's Part of a Winter (1978, the Colorado mountains); and Anne LaBastille's Woodswoman (1976) and Beyond Black Bear Lake (1987, the Adirondacks).

The sheer repetitiveness of such works, not to mention the mediocrity of most of them, has naturally called into existence a literature of parody, indeed sometimes (as in Sibley's case) a vein of self-parody interacting with more serious elements in the same piece. Among lighter treatments, perhaps of the best and certainly the best known are E. B. White's occasional essays, such as "Walden-I954" which contains a serio-comic description of the boathouse-workshop ("that, through no intent on my part, is the same size and shape as his own domicile on the pond") where the author's essay is being written. "I have learned," White continues, with mock-Thoreauvian solemnity (or is it Thoreauvian mock-solemnity?) "that in most respects it shelters me better than the larger dwelling where my bed is, and

22 Philip G. Hubert, Jr., Liberty and a Living (New York: G. P. Putnam's, 1889) pp. I 71-90; Paul Elmer More, "A Hermit's Notes on Thoreau," Atlantic, 87 (1901), 857-64; Lewis Leary, "Walden Goes Wandering," New England Quarterly, 32 (1959), 3-30 (on Thoreau and van Eeden); Seymour L. Flaxman, "Thoreau and van Eeden," Thoreau Abroad, ed. Eugene Timpe (Hamden, Conn.: Archon, 1971), Pp. 61-69; Joseph Jones, "Thoreau in Australia," ibid., pp. I86-92.

${ }^{23}$ See for example, New England Quarterly, 2 (1929), 694 (Van Wyck Brooks's review of Beston), and San Francisco Chronicle, 27 Nov. 1949, p. 28 (review of Leopold by J. W. H., rpt. Book Review Digest 1949, p. 549). 
which, by design is a manhouse not a boathouse." ${ }^{24}$ Here and elsewhere White gently mocks modern sylvan gestures, as well as the owlish rhetoric of the guru himself. White is well aware of living on the threshold of an era when the man who discovered Thoreau's cabin site and built the first replica would be flooded by mail orders when he advertised Thoreau cabin kits for $\$ 4,000$. But neither the kits nor White's essay would have sold unless Thoreau's gesture continued to be taken on another level as gospel truth. The mainstream of Walden imitation continues to be borne by accounts like At Home in the Woods: Living the Life of Thoreau Today by a Bostonian couple that become homesteaders in Hudson Hope, British Columbia, with Walden as their scripture. Their first sentence reads: "We went to the wilderness because ıo years ago a man wrote a book." 25

The decentralization of the Walden pilgrimage seen in the experiments of Seib, Byron, Sibley, and the Angiers has come about not only as a result of Thoreau's Transcendentalist dicta against conformity but also because devotees have rightly sensed Thoreau's own retreat to be the enactment of a more fundamental ritual of which he himself was hardly the originator. To use the Turners' typology, Walden excursions like Muir's represent a combination of "prototypical pilgrimages"-i.e., those established by the founder of the cult, by the first disciples or important national evangelists - and "archaic pilgrimages," those which bear traces of older beliefs and symbols. ${ }^{26}$ Although Thoreau's Walden retreat has become the most memorable American example of the civilized person's withdrawal to a simpler state of existence for the sake of spiritual refreshment, its authority derives not so much from its own originating power as from the fact that versions of it date back at least two millennia, in both western and oriental culture, and had begun to take on new authority from the time New England settlement began to be conceived as an errand into the wilderness. Thoreau's

24 "Walden-1954", Yale Review, 44 (1954), 16-17.

25 Vena and Bradford Angier, At Home in the Woods (New York: Sheridan House, 1951), p. 100.

26 Image and Pilgrimage, p. 18. The study of Thoreau that comes closest to a comprehensive analysis of his record of the Walden experience as a cultural archetype is Leo Marx's The Machine and the Garden: Technology and the Pastoral Ideal in America (New York: Oxford Univ. Press, 1964), especially pp. 242-65. 
experiment had a wealth of American precedents, from the near at hand (like his college classmate Charles Stearns Wheeler's cabin-living experiment a few years earlier) to the long ago (the first settlement of the town of Concord); and the narrative he published about it had its precursors too: John Filson's chronicle of Daniel Boone, Cooper's The Pioneers, Joel T. Headley's The Adirondack: or Life in the Woods.

For the Concord pilgrimage to become seen, over the years, as increasingly culminating at Walden is therefore symptomatic not merely of the rise of Thoreau's personal reputation but, more broadly, of an American apotheosis of pastoral retreat that was inherent in the earliest institutionalization of Transcendental Concord as a cultural shrine and that was itself a heightened form of a root paradigm manifested in many world cultures, east and west.

Yet shrines also require saints. "All sites of pilgrimage," the Turners state, "have this in common: they are believed to be places where miracles once happened, still happen, and may happen again. Even where the time of miraculous healings is reluctantly conceded to be past, believers firmly hold that faith is strengthened and salvation better secured by personal exposure to the beneficent unseen presence of the Blessed Virgin or the local saint, through a cherished image or painting." ${ }^{27}$ Here again, the case of Thoreau is surprisingly pertinent. Though the Walden pilgrimage might not have evolved without the sense that Thoreau's retreat was culturally representative, the enactment of some sort of root paradigm, neither would it have evolved at Walden if Thoreau had not gone there. Let us look briefly at how the figure of Thoreau became invested with pastoral sainthood.

Most obviously crucial in the hagiographical process is of course Walden itself: a central source of supply of the equivalent of the mediating images through which traditional pilgrims experience the local saint as saint. Their magic arises in good part from Thoreau's ability to invest even small gestures with ritual significance. His morning bath is a religious exercise, his hut a

27 Image and Pilgrimage, p. 6. 
hermitage. In "Higher Laws" he espouses a saddhu-like asceticism; in "Spring" he experiences the renewal of the season as a resurrection from the dead. In Walden's later companion-piece, "Walking," Thoreau authorizes his reader/devotee to think of the whole process of nature rambling as "sauntering" in the sacred sense - as a kind of Holy Land pilgrimage. ${ }^{28}$

Nowhere does Thoreau directly claim sainthood; on the contrary, he often treats his solemn aspirations lightly, as in Walden's hermit-poet dialogue following "Higher Laws," where the hermit's pious resolve evaporates as soon as he is invited to go fishing. Thoreau's friends and followers, however, were quick to make bigger claims for him, and his own capacity for selfrighteous rhetoric has helped to make them stick. Emerson and the Alcotts thought of him as the Concord Pan, the fluteplaying god of nature. It was repeatedly alleged in the nineteenth century that Thoreau was the model for the Pan-like Donatello in Hawthorne's Marble Faun. ${ }^{29}$ Many people, both friends and casual visitors, told stories in wonderment of Thoreau's mysterious-seeming ability to charm the forces of nature. "I am sure he knew the animals one by one," declared Alcott; "the plants, the geography, as Adam did in his Paradise, if, indeed, he were not that ancestor himself." ${ }^{30}$ "The most striking of these testimonials, reported in almost identical form by two independent witnesses, concerns how Thoreau liked to entertain children of friends who visited him at Walden. Here is one version of the story as told in adulthood by one of the delighted children.

He was talking to Mr. Alcott of the wild flowers in Walden woods when, suddenly stopping, he said, "Keep very still and I will show you my family." Stepping quickly outside the cabin door, he gave a low and curious whistle; immediately a woodchuck came running towards him from a nearby burrow. With varying note, yet still low and strange, a pair of gray squirrels were summoned and approached

28 Thoreau, Excursions (Boston: Ticknor and Fields, 1863), pp. 161-62. For a concise, suggestive treatment of ritual gestures in Walden, see Reginald Cook, "Ancient Rites at Walden," Emerson Society Quarterly, 39 (1965), 52-56.

${ }^{29}$ The Journals and Miscellaneous Notebooks of Ralph Waldo Emerson, ed. William Gilman et al. (Cambridge: Harvard Univ. Press, 1960-82), X, 344; Louisa May Alcott, “Thoreau's Flute," Atlantic, 12 (1863), 280-81; A. Bronson Alcott, sonnet 13 of Sonnets and Canzonets (Boston: Roberts, 1882); Edward C. Peple, Jr., "Thoreau and Donatello," Thoreau Journal Quarterly, 5 (1973), 22-25.

${ }^{30}$ Alcott, Concord Days (Boston: Roberts, 1972), p. 14. 
him fearlessly. With still another note several birds, including two crows, flew towards him, one of the crows nesting upon his shoulder. I remember it was the crow resting close to his head that made the most vivid impression upon me, knowing how fearful of man this bird is. He fed them all from his hand, taking food from his pocket, and petted them gently before our delighted gaze; and then dismissed them by different whistling, always strange and low and short, each little wild thing departing instantly at hearing its special signal. ${ }^{31}$

Thoreau makes passing reference to making friends with mice and birds in "Brute Neighbors"; but it was chiefly by report of those who had known him that his reputation for occult mastery over nature became established, and most especially through an oft-quoted passage of Emerson's funeral tribute: "Snakes coiled round his legs; the fishes swam into his hand, and he took them out of the water; he pulled the woodchuck out of its hole by the tail, and took the foxes under his protection from the hunters." ${ }^{32}$ Today we know that Thoreau's woodland miracles can all be duplicated by other sufficiently patient nature-watchers, and that Native American sages could probably do all Thoreau could and more centuries before he learned to do it. But that is not the point: the point is the sense of wonderment that Thoreau's woodsmanship aroused in his friends and visitors.

Emerson's tone in reporting his list of wonders is of course playful and cosmopolitan, implying his usual condescension toward such forms of competence and perhaps also his awareness of a certain histrionic quality in Thoreau himself. But the net effect was to mysticize Thoreau and set the stage for further mysticization by his biographers. Ellery Channing came first, insisting in his appendix of "Memorial Verses" on the curative powers of Thoreau's writing:

For thoughtful minds in Henry's page

Large welcome find, and bless his verse,

Drawn from the poet's heritage,

From wells of right and nature's source.

Fountains of hope and faith! inspire

Most stricken hearts to lift this cross,

31 Frederick L. H. Willis, reported in Alcott Memories (1915), rpt. in Walter Harding, ed., Thoreau: Man of Concord (New York: Holt, 1960), p. 134.

32 "Thoreau," Complete Writings, ed. Edward Emerson (Boston: Houghton Mifflin, I903-04), X, 472. 
His perfect trust shall keep the fire,

His glorious peace disarm the loss! ${ }^{33}$

Here and elsewhere in his poetry, Channing bears out what Emma Lazarus said of him: that he "actually worships" the memory of Thoreau. ${ }^{34}$ Although, like Emerson, Channing was not above amusing himself at Thoreau's expense, he typically portrays Thoreau as a holy hermit, a beneficent spiritual influence, etc. In short, when Channing (the model for the interlocutor in Thoreau's hermit-poet-dialogue) came to writing his side of the story, the drollery tended to evaporate and the solemnity to be heightened.

The same was even more true of Thoreau's second biographer, A. H. Japp, an English gentleman-reformer who (and this is significant) knew Thoreau exclusively through the medium of his writings and published testimony. It was Japp who first propagated the comparison between Thoreau and St. Francis of Assisi, on the strength of their reverence for fellow creatures and their uncanny power over the animal kingdom. In formulating this unabashedly hagiographical version of Thoreau, Japp relied especially on "Brute Neighbors," Emerson's eulogy, and the more effusive memoirs of Channing and minor Transcendentalist Moncure Conway. ${ }^{35}$

Japp's Thoreau-as-Saint-Francis was poo-poohed by some reviewers, and no later Thoreauvian critic has taken it as seriously as its perpetrator; but it has often been repeated, too, and the analogy is still very much alive today. Joseph Wood Krutch, for example, called it "banal" but went on to draw a very solemn distinction between the two figures that worked greatly to Thoreau's advantage: seeing St. Francis as anthropocentric in forcing Christian doctrine on the birds, and Thoreau by comparison as imbued with a more truly ecological gospel of reverence for fellow creatures as equals. ${ }^{36}$ This was a historic re-

33 Thoreau: The Poet-Naturalist (Boston: Roberts, 1873), p. 329.

34 Quoted in Frederick T. McGill, Jr., Channing of Concord (New Brunswick: Rutgers Univ. Press, 1967), p. 169.

35 Japp, Thoreau: His Life and Aims (Boston: Osgood, 1877), pp. 1-14, 44-63; Conway, "Thoreau," Fraser's Magazine, 73 (1866), 462.

36 "Prologue" to Krutch's ed. of Great American Nature Writing (New York: Sloane, I950), pp. 5-6. Important concurrent essays by Krutch are "Little Fishy Friend," Nation, I69 (1949), 350-51; and "A Kind of Pantheism," Saturday Review, 33 (10 June 1950), 7-8, 30-34. Krutch makes Thoreauvian respect and empathy for nature as humanity's equal the chief criterion for distinguishing the ethos of modern vs. premodern nature writing. 
casting. In effect, Krutch sought to define a new dispensation of ecological consciousness in which humankind would be emancipated from the anthropocentrizing way Judaeo-Christianity has tended to deal with the environment, and to make a case for Thoreau as its patron saint. ${ }^{37}$

The St. Francis analogy, however, is only one of many forms that the apotheosis of Thoreau has taken. The more important point is that many of those who have thought about him during the past century, including a number of scholars, have liked to envisage him as a larger-than-life being, even as some of these same folk have enjoyed tweaking his feet of clay from time to time. The Angiers, for instance, don't compare him to St. Francis but do think of him as the infallible guide. The one moment when their faith falters, after returning to civilization (as Henry did) and finding themselves unhappy about it, is especially touching, albeit gooey. Brad sadly opines that Thoreau "must have been wrong in leaving the woods when all that meant so much to him. Yet he was so right in everything else." To which Vena, fortunately, is able to make this bright reply: "'But he was never really wrong, not in real life. That's where we made our mistake.' I managed to smile, and I lifted my face. His questioning lips touched mine, warm and alive. 'Thoreau left his cabin, yes. He didn't mention the rest of it in that book we have, but. . . . He spent the rest of his time roaming about the same woods, the same fields, and the same Walden Pond." "38 This realization gives the couple the reassurance they need to return to their own cabin. They don't pray to St. Henry, exactly, but they might just as well have. Here as many times before they invoke their patron, and, lo, their problem is solved. For them and other such readers, it's not so much the specific doctrinalization of Thoreau as saint that counts as the elevation of Thoreau to the status of model or prototype of whatever sort.

\section{V}

After having made this point, however, it is important to repeat that the patron is the center of an ideological system and

${ }^{37}$ In this respect, Krutch anticipates the influential albeit simplistic contemporary tradition of blaming Judaeo-Christianity for technology's sins against the environment. The seminal indictment is Lynn White, "The Historical Roots of Our Ecologic Crisis," Science, 155 (1967), 1203-07.

38 Angier and Angier, p. 251. 
not the whole system. That too is a common denominator of the tributes cited above. The system varies. For Channing it is the ethos of the romantic poet-prophet; for Japp, Christian asceticism; for Krutch, modern ecological consciousness; for the Angiers, the homesteaders' way; for Seib and Sibley, a temporary moratorium from the work ethic. But in each case there is a larger symbolic system. If we return to the case of John Muir, we can see at least two such systems at work. One is a merger of the perspectives of Channing and Japp: a late-romantic secularized Christianity that looked at nature as primary revelation, displacing scripture and worship service. Muir's earlier description of his own first months of cabin-living in Yosemite is most revealing here:

I am sitting here in a little shanty made of sugar pine shingles this Sabbath evening. I have not been at church a single time since leaving home. Yet this glorious valley might well be called a church, for every lover of the great Creator who comes within the broad overwhelming influences of the place fails not to worship as he never did before. The glory of the Lord is upon all his works; it is written plainly upon all the fields of every clime, and upon every sky, but here in this place of surpassing glory the Lord has written in capitals. ${ }^{39}$

What authorizes Muir's experience of subsistence living in this natural paradise, which from a practical standpoint looks cranky and unproductive and anti-social, is the sense of holiness-withinnature to which he can appeal as an extension of the paradigm of piety shared by his Christian-reared and also nature-sensitive siblings. It was clearly not just the figure of Thoreau, whose masterpiece Muir had not yet read, but the sense of something like a shared paradigm, as well as a shared literal experience of retreat, that enabled Muir to respond as he did when he visited Concord. (Muir, incidentally, was just as capable as Thoreau of editing the bald facts in order to make his symbolic world luminous. The passage just quoted fails to indicate that the hut isn't freestanding out in nature but is attached to a sawmill.) When Muir's published prose echoes Thoreau's, as it frequently does, it is not so much that Muir has deliberately remade himself in Thoreau's image as that Thoreau's vocabulary seems congenial 
as a kindred expression of the holiness of the pristine places of the earth.

The other paradigm that made Muir's Concord visit luminous had nothing specifically to do with nature but rather with the system of cultural accreditation that had drawn Howells there thirty-three years before. Concord stood for the cultural establishment on whose margins the largely self-educated outlander Muir felt himself to be. Whether or not we credit Muir's insinuation that he visited Concord because Johnson dragged him there, his way of broaching the point shows his awareness of Concord as an establishment shrine. The ease with which Johnson later overcame Muir's resistance to the bother of trekking east to be degreed at Harvard in the kind of ceremonial display from which he habitually shied shows how receptive this exfarmboy was to the prospect of becoming an institution himself. Atlantic editor Walter Hines Page knew his man when he was careful to stress in his courtship of Muir that his magazine and the press that owned it (Houghton Mifflin) published the most prestigious list of authors in America-backing the appeal to prestige with a better contributor's wage and royalty contract than he had received from Johnson's firm. ${ }^{40}$

Muir's experience of natural piety at Sleepy Hollow, then, was clearly heightened by the sense that "great men" rested there; the bucolic moment at Walden was no more delicious than Edward Emerson's father-in-law recognizing him as "a long lost son." And the whole ensuing stay in greater Boston was rendered even more delightful for being hosted by his wellto-do Brahmin botanist friend Sargent at his elegant Cambridge home- "the finest mansion and grounds I ever saw." ${ }^{41}$ Specialized students of Emerson's and Thoreau's reputations are normally solicitous to distinguish between their relative status in nineteenth-century Concord: between the genteel Emerson, for whom all was forgiven in view of his pedigree and good manners, and the prodigal son Thoreau, borderline gentry to start with and downwardly mobile by his own perverse intent.

40 For the pertinent evidence, see the $1897-99$ correspondence between Muir and R. U. Johnson, W. H. Page, and C. S. Sargent, reels 9-10 of the microfilm edition of Muir's unpublished mss.

41 Bade, II, 270. 
But to most late-century outlanders, Concord was first of all a global impression of portentousness: "the biggest little place in America." 42 That established, finer distinctions could then be made, of course. But first of all, even by the time of the Civil War, Concord was, as the journalists liked to say, "classic ground." A cultural reference point, whose collective literary achievement emanated a certain power.

The subsequent correspondence between Atlantic editor Page and favored contributor Muir is a gloss on that power. "The greatest single compact body of American literature of permanent value that exists anywhere is put forth by this firm," Page - a fellow outlander-reminds Muir. "This single fact gives the firm an advantage that no other one has in putting writings which have sufficient merit first alongside of this compact mass of permanent literature and finally into it -thus bringing about not simply such a sale of a book as can be made so long as it is a new publication, but in addition thereto such a continual nurture of it as a piece of literature as will keep it alive as long as it has any vitality whatsoever." ${ }^{43}$ In his genial, florid, confident, relentless way, Page harped on this same string again and again. In actual fact, the Houghton/Atlantic establishment had passed its peak of prestige; but from an I 890 os contributor's perspective, given his firm's fifty-year track record of success, Page's argument looked very strong, and it is understandable that Muir would have been impressed by it. Concerning recent literary history and indeed even literary history as subsequently rewritten, Page's claims about canonization were not overbold: the Ticknor-Fields publishing empire that evolved into Houghton Mifflin was in fact the single literary institution most responsible for forming the first national canon and for sponsoring the work of the majority of the premodern American writers that are most widely considered "major" even today. Henry Thoreau is a case in point. Although his most ardent publisher-friend was Horace Greeley, it was Ticknor and Fields who made his reputation with Walden; it was Fields who kept him before the public in the 1860 in a series of Atlantic articles (not to mention reviews of Thoreau's posthumous books and references to Thoreau in 
many other articles); it was Houghton Mifflin that eventually brought out Thoreau's journal, first in excerpts during the 1880 os and I89os, then in its entirety (1906); and it was Houghton Mifflin that published the authorized complete editions of his work.

Concord, then, represented the intertwined forces of American nature and American literary culture, as the hundreds of touristical guidebooks that began appearing in the late nineteenth century were quick to underscore. Concord was "our literary Mecca," attracting by the I 890 os if not before "more pilgrims than any other place of equal size upon the continent," not only because of its Revolutionary fame but because the Transcendental coterie "helped the village of Concord do more for American literature than has any great metropolis of the nation." ${ }^{44}$ Yet it and particularly Walden retain their pastoral charm withal. "Commercialism is a thing of which Concord does not boast" (1902); "Much of the Pond's natural beauty is still present" (I929); “Thoreau's cove, and the woods surrounding it, are still peaceful, and the lover of Thoreau will not find here too great interruption of his thoughts" (1936). ${ }^{45}$ Of course these are statements of what the writers wanted their readers to see, rather than what actually was. But the point is not their mimetic accuracy but their desire to associate Concord with both nature's power and culture's power. Thoreau's reputation initially benefitted from his association in both respects with the Concord group, particularly Emerson; increasingly, since the turn of the twentieth century, he has become the principal raison d'être for Concord's continued existence as a shrine. So long as Thoreau continues to be seen as an American cultural hero, namely, as long as the interlinked values of pastoralism and counter-culturalism remain cherished parts of the American cultural heritage, the present configuration is likely to remain.

44 Concord: A Few of the Things to Be Seen There (Concord: Patriot Press, 1902), p. 3; Concord: A Pilgrimage to the Historic and Literary Center of America (Boston: Perry Walton, 1925), p. I ; Theodore F. Wolfe, Literary Shrines: The Haunts of Some Famous American Authors (Philadelphia: Lippincott, 1895), pp. 17-18; O. G. Seeley, Views and Descriptive History of Lexington and Concord (Lexington: Seeley, 1901), p. 50.

45 Albert Lane, Concord Authors at Home (Concord: Erudite Press, 1902), p. 22; Charles Ferguson, A Historical Sketch of the Town of Concord (Concord: pvt., 1929), p. 21; A Leaflet Guide to the Points of Interest in Historic Concord (Concord: Concord Antiquarian Society, 1936). 


\section{VI}

In conclusion, here are some summary reflections on the general value of studying Thoreau in terms of the rituals of devotion that have built up around his most famous book and the symbolic gesture that led to it. First, it confirms that canonization is assisted and sustained by good connections, but also that this process is regulated by larger ideological patterns that stand partially in alignment but also partially at odds with those material advantages. Thoreau's reputation benefitted from his connection with the literary and publishing power-centers, but also from the impression that he stood outside those centers: that to approach the ghost of Thoreau meant shaking the dust of urbanity and materialism from one's feet, indeed ultimately civilization itself -as with Muir's daydream of a 2,00o-year sojourn by the pond. In this we see not only the capacity for pilgrimage to promote cozy smugness but also its capacity to reinforce an antisocial commitment.

Second and related, sanctifying rituals of remembrance are apt to be promoted most by the relatively conventional-minded, although sanctification does not equate with normalization. The conservative side of canonical investment is exemplified by the tendency of the pilgrimage literature examined above to crystallize into prefabricated genres: the Concord guidebook and the narrative essay or epistle. As guidebooks and visitation narratives multiplied around the turn of the century, the intensity of the represented experience became muffled in cliché. Even debunking narratives written in attack against touristical commercialization-a thriving minority subgenre I have regrettably shortshrifted here-become themselves routinized mirror-stereotypes of the straight-faced accounts. This process partly resulted from the inertia of textuality, partly from the limited horizons of the reporters. Published accounts of pilgrimages to literary shrines are by definition produced by literate individuals with access to the media; unpublished reports will most often be preserved when written by public figures with sufficient prestige in their communities to warrant embalming their relics. Small wonder, then, that the hundred or so narratives like Muir's that formed the chief data base for this study were all written by whites, at least four-fifths of them males occupying or desirous of occupy- 
ing positions of literary respectability. The establishment character of this cohort undoubtedly has something to do with the cultural limits of Thoreauvian pastoral as a charismatic force, but almost surely the literary pilgrims were something less than a cross-section of Thoreau's admirers. The more radical and original among those, Gandhi and Martin Luther King for instance, are less likely to be interested in shrine-building than in enacting their own independent pilgrimages. This can be surmised from Muir's case, too: his self-consciousness and recalcitrance at being drafted into literary tourism, as against the much more infectious enthusiasm with which he acted out his own Thoreauvian role at Yosemite. And to the extent that Muir's belated discovery of Thoreau as an inspirational force helped equip him with a rhetoric and an ethos of empowerment on behalf of the unpopular doctrine of preservationism, we see in Muir's "discipleship" also the potential of the canonized figure, who by definition is extraordinary, to instigate resistance to normalization, especially when that figure is linked in the public mind to a story of secession from norms.

Finally, the phenomenon of canonical investment alerts us to the parochialism of the text-centered kind of appraisal of a writer's canonical stature that comes most naturally to literary scholars. It is not just the texts that are canonized, but the figure, especially in the case of an autobiographical writer like Thoreau; and the imaginative bond of devotee to writer probably operates less at the level of the reading experience than we normally think. By the same token, the consequences of canonization should be measured less than scholars normally do in terms of texts (or criticism) engendered than in terms of lives led. The case of Thoreau, anyhow, forces us to take seriously the question of whether the Angiers are closer to understanding the kingdom of Henry than those who have fathomed him mainly on the level of his rhetorical sophistication. 